\section{Birlesik Dunya Arastrma Cypriot Journal of Educational \\ Sciences}

Volume 16, Issue 4, (2021) 1704-1720

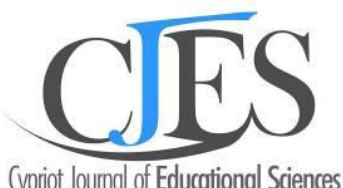

Cypriot Joumal of Educational Sciences

www.cjes.eu

\title{
Improvement of principals' supervision competence through accompaniment in principal working groups
}

Nurlaili Nurlaili a*, Mulawarman University, Faculty of Teacher Training and Education, Jl. Muara Pahu, Samarinda, East Kalimantan, Indonesia. https://orcid.org/0000-0001-5019-9802

Warman Warman b, Mulawarman University, Faculty of Teacher Training and Education, Jl. Muara Pahu, Samarinda, East Kalimantan, Indonesia. https://orcid.org/0000-0001-9554-4366

Raolah Raolah c, Technical Implementation Unit of the Sangkulirang District Education Office, East Kutai Regency, East Kalimantan, Indonesia. https://orcid.org/0000-0003-4348-7739

\section{Suggested Citation:}

Nurlaili, N., Warman, W., \& Raolah, R., (2021). Improvement of principals' supervision competence through accompaniment in principal working groups. Cypriot Journal of Educational Science, 16(4), 1704-1720. https://doi.org/10.18844/cjes.v16i4.6033

Received from March 10, 2021; revised from June 12, 2021; accepted from August 10, 2021. (C)2021 Birlesik Dunya Yenilik Arastirma ve Yayincilik Merkezi. All rights reserved.

\begin{abstract}
A principal's supervision competency affects the improvement in the teaching and learning process; therefore, it needs to be improved. This study aimed to describe the principal working group (PWG) activities and the principal's supervision competencies after being assisted by school supervisor in the PWG at Sangkuang Island, East Kutai Regency. This research used a qualitative method and was conducted at state elementary schools. Data collection used interview, observation and documentation techniques. The data were analysed using Miles and Huberman's model. The results showed that the PWG activities were effective and the principals could exchange ideas and solutions to solve school problems. The school supervisor's assistance in the PWG activities increased the principal's supervision competencies. The principals were able to plan supervision programmes properly, conduct standard supervision and implement follow-up supervision according to the needs. This study implies that a school supervisor's assistance is important to improve the principal's supervision competence and this can be adopted at other area.
\end{abstract}

Keywords: Elementary school, principal, supervision competence.

\footnotetext{
* ADDRESS FOR CORRESPONDENCE: Nurlaili, Faculty of Teacher Training and Education, Mulawarman University, Jl. Muara Pahu, Samarinda, East Kalimantan, Indonesia, 75123.

E-mail address: nurlaili@fkip.unmul.ac.id / Tel.: +62-82154687383
} 


\section{Introduction}

Succeeding or not, an educational institution, especially in the education unit, is strongly influenced by the competence of the principal. The principal's competencies are formed based on five indicators that are comprehensive and synergistic, namely 1): managerial competency, 2) supervision competency, 3) entrepreneurial competency, 4) social competency and 5) personality competency. The principals must possess the competency to carry out their role and function professionally and work effectively and efficiently to realise a quality school (Alfian et al., 2019; Hidayat \& Ulya, 2019; Wiyono et al., 2020).

Among the five competencies of principals, supervision competency is an essential competency owned by the principal because the supervisory competence of the principal is implemented in academic supervision activities in schools that directly affect teacher performance (Ramadhan, 2017; Trinh et al., 2019; Yasin \& Mustafa, 2020). If the teacher's performance is good, then the learning process will be with quality, which facilitates the achievement of educational goals. The supervision of the principal is also called academic supervision.

Academic supervision competency is the ability of the principal to foster teachers to improve the quality of the learning process (Arman et al., 2016). The target of academic supervision is teachers in carrying out the learning process. The supervised component consists of learning equipment and classroom management. However, the results of pre-research through observations and interviews show that not all principals have good supervision competencies, especially the principal of SD Negeri in Sangkuang Island. Some of the initial findings that occurred are as follows: (1) supervision conducted by the principal has not been appropriately planned, so the supervision schedule is not clear; (2) the implementation of the supervision of the principal has not been guided by the correct process; and (3) follow-up to the implementation of supervision is not carried out, so there is no feedback.

This problem is caused by the principal lacking knowledge and insight about the supervisory competence. The supervisory competencies of the principal include 1) planning an academic supervision programme in order to improve teacher professionalism, 2) implementing academic supervision using the right approach and supervision techniques and 3) following-up on the results of academic supervision in order to improve teacher performance. Supervision is a process specifically designed to help teachers use their knowledge and abilities to provide better (Astuti, 2017; Syafmawati, 2020).

School superintendents play an essential role in improving and developing the supervisory competence of the principal. The task of the school superintendent is to provide assessment and guidance ranging from programme plans, processes and results in the school management to improve school performance. The responsibility of the school superintendent is to help improve the quality of education and the teaching and learning process.

In carrying out the task, the principal needs a professional organisation to develop its performance. The current professional organisation of the principal is the principal working group (PWG). PWG members consist of all principals in a specific school cluster. The headmaster needs input from fellow principals to discuss and find solutions to school problems. To improve the competence of the principal, the PWG can be empowering. 
It is important to note that Sangkuang Island is a remote island located in Sangkulirang Bay, East Kutai Regency, East Kalimantan, Indonesia. The supervision competency of the primary school principal in Sangkuang Island needs to be improved because the supervision competency directly impacts the quality of the teaching and learning process. The quality of the teaching and learning process is one of the most determining indicators of whether or not education is successful in schools.

Some studies have been conducted and show a positive influence of the headmaster's supervision competency on teacher performance (Khun-Inkeeree et al., 2019; Kotirde \& Yunos, 2015; Maskur et al., 2018). The competence of school supervisors and principals positively influence the motivation and performance of junior high school teachers in Maros (Arman et al., 2016). In addition, Murtiningsih et al. (2019) reported that there was a significant relationship between the supervision of the principal and the spirit of teacher work. The research generally discussed the relationship between the principal's supervisory competence and the teacher's performance. However, researches on the improvement of the principal competence through the assistance of school supervisors with PWG activities have not been reported, especially in the Sangkuang Island. Therefore, this study was conducted to describe the activities of the PWG and the competence of the principal's supervision on the planning, implementation and follow-up of academic supervision in the school after being assisted by the by the school supervisor.

The problem in Sangkuang Island is the competence of the primary school principal, and so it needs to be improved. So in this study, we look for solutions to improve the supervisory competence of the principal.

\section{Methods}

The competence of principal supervision is significant for the principal because it can improve teacher performance in the implementing the learning process (Yasin \& Mustafa, 2020). Therefore, school supervisors as supervisors for school principals are sought to improve supervisory competence through PWG activities. This study aims to describe the phenomenon that occurs, the condition of the principal's competence after coaching by the school supervisor. Besides, it describes the process of guidance by school supervisors in PWG activities. A qualitative approach with a descriptive method helps explore what supervisors, principals and teacher's experience, about their behaviour, perceptions, motivation and actions. Information is conveyed holistically and through descriptions in the form of words (Moleong, 2017; Hudiyon et al., 2021; Rokhmansyah et al., 2021).

This research was conducted at public elementary schools on Sangkuang Island, Sangkulirang District, East Kutai Regency, which consists of four schools as follows: 1) public elementary school 003 Sangkulirang; 2) public elementary school 006 Sangkulirang; 3) public elementary school 007 Sangkulirang; and 4) state elementary school 012 Sangkulirang. On Sangkuang Island, there are only four public elementary schools, and all of them were used as research samples. In Figure 1(b), Sangkuang Island is marked by a circle. 

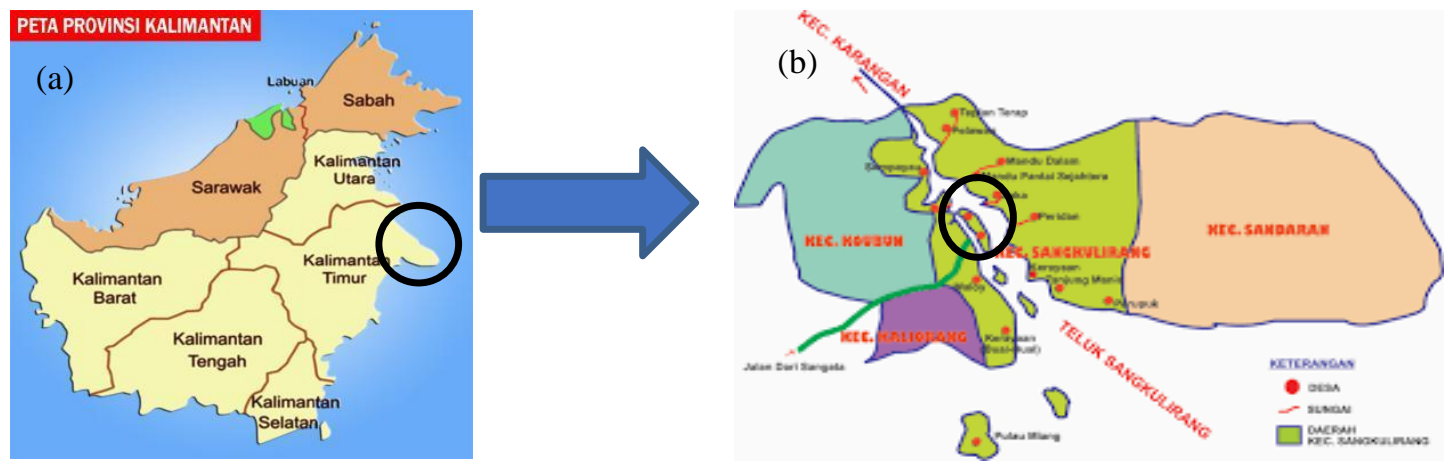

Figure 1. (a) Kalimantan Island and (b) Sangkuang Island in Sangkulirang Bay

\subsection{Data collection techniques}

The collection of data in this study was through interview, observation and documentation techniques. Each of them is described below.

\subsubsection{Interview techniques}

Interviews were conducted to obtain direct and in-depth information from research informants. The interview technique used was an unstructured interview, in which the researcher prepared interview guidelines. During the interview, questions were developed to obtain more in-depth information, but this could not be separated from the interview guidelines that were established. In this study, the research informants were school supervisors, school principals and teachers of public elementary schools on Sangkuang Island. From the three informants, it was hoped that information would be obtained holistically about the implementation of coaching by school supervisors for the principals of the state elementary school on Sangkuang Island. Interviews used voice recordings so that the information obtained can be heard repeatedly and analysed. There were three types of interview guidelines, namely interview guidelines for school supervisors, school principals and teachers.

The interview guidelines focused on two activities, namely PWG activities and academic supervision. PWG activities are discussion forums for school principals who are supervised by school supervisors. Therefore, the data mining PWG activities are sourced from school supervisors and school principals. In essence, the questions for school supervisors and school principals are almost the same as they relate to PWG activities. The interview guidelines about PWG activities were developed based on the PWG function as a discussion forum for school principals. The PWG objectives were as follows: 1) knowing the problems and difficulties of schools related to planning, implementation and evaluation; 2) overcoming difficulties by school principals; and 3) developing the professional abilities of school principals. The school supervisor was the accompaniment of the PWG activities.

Extracting information about the implementation of school principal academic supervision came from school supervisors, school principals and teachers. In this activity, the principal acts as a supervisor, the teacher acts as a learning process implementer and the school supervisor acts as a supervisor. The interview guidelines were created using information from the Minister of National Education's Regulation No. 13 of 2007 concerning Principal Qualifications, which specifies that school principals must possess four skills: 1 ) administrative competence, 2) entrepreneurial competence, 3 ) 
supervisory competence and 4) personality competence. In the supervision competency section, it is written that the principal must be able to 1) plan an academic supervision programme, 2) carry out academic supervision using appropriate techniques and 3) follow-up on the results of academic supervision of teachers to increase teacher professionalism (Astika et al., 2020).

Interview guidelines for school supervisors, aimed at gathering information about: 1) the presence of school supervisors at PWG activities; 2 ) the role of school supervisors in PWG activities; 3 ) the material discussed in PWG activities; 4) the performance of the principal in the field of academic supervision which includes planning, implementation, assessment and follow-up carried out by the principal; and 5) the principal's ability to solve problems after participating in PWG activities.

Interview guidelines for school principals asked about 1) principals' perceptions of PWG activities and the extent of school principals' interest in PWG activities, 2) the role of school supervisors in PWG activities, 3) material discussed in PWG activities and 4) performance of school principal's supervision after participating in the PWG. This section addresses the principal's motivation and how to find the best solution if he finds obstacles in carrying out his tasks. In addition, a core question is how the principal carries out academic supervision at school, starting with planning, implementation, assessment and follow-up activities.

Interview guidelines for teachers contain the following: 1) planning for academic supervision to be carried out by the principal, 2) implementation of academic supervision, 3) assessment and followup of academic supervision and 4) teacher's perceptions about the competence of the principal in carrying out his function as an academic supervisor after participating in PWG activities.

The main questions in the interview were almost the same. The answers obtained from the informants were cross-checked with each other until a valid answer was obtained.

\subsubsection{Observation techniques}

Observation is an essential element in qualitative research because the data from the observation results are the actual conditions of the objectives of research. The observations made were passive participatory observations, in which the researcher came to the place of the activity of the person being observed but was not involved in the activity. In addition, observation was carried out openly, meaning that the subject being observed knows that the activity is being observed.

Through observation, researchers could observe for themselves the social situation in the school, which is the background of the research, the behaviour of the principal when conducting academic supervision, the interaction between the principal and the teacher, the behaviour of the principal and the interpersonal interactions that occurred in PWG activities and the interaction between school supervisors and school principals. Besides, observation will provide a clearer picture of the incomplete information during the interview. Thus, it makes it easier for researchers to describe the behaviour of the subject and the process of events within the scope under study. In this study, the objects observed were 1) activities of supervising school supervisors in PWG activities and 2) supervision of school principals in their respective schools. The PWG activity observation form and academic supervision activities are shown in Tables 1 and 2.

\subsubsection{Documentation techniques}

The research results from interviews and observations would be more credible or trustworthy if they are supported by documents of any events or incidents related to the research data. Documents can be in the form of writing or images. In this study, the supporting documents of the data include 
school academic supervision programme, supervision instruments, supervision schedule, photos of the implementation of supervision, reports on the results of supervision and evaluation. Documents in the form of pictures are photos of PWG activities.

Table 1. The PWG activity observation form

\section{OBSERVATION FORM}

Object of observation : PWG activity

Place of observation:

Time of observation :

Type of observation : Descriptive

\begin{tabular}{|l|l|l|l|}
\hline No. & Aspect observation & \multicolumn{1}{|c|}{ Sub-aspects } & Description of observation results \\
\hline 1 & Condition of activities & $\begin{array}{l}\text { Presence of school } \\
\text { principals attendance of } \\
\text { school }\end{array}$ & \\
\cline { 3 - 4 } & & Supervisors & \\
\hline 2 & $\begin{array}{l}\text { Delivery of material by } \\
\text { school supervisors }\end{array}$ & Material presented & \\
\cline { 3 - 4 } & & $\begin{array}{l}\text { Situation when delivering } \\
\text { material }\end{array}$ & \\
\hline 3 & $\begin{array}{l}\text { Interactions between } \\
\text { school supervisors and } \\
\text { principals who are }\end{array}$ & & \\
\hline 4 & $\begin{array}{l}\text { Interactions between } \\
\text { school principals }\end{array}$ & & \\
\hline 5 & Discussion activities & Discussion situations & \\
\hline 6 & $\begin{array}{l}\text { Asking activities of } \\
\text { school principals to } \\
\text { school supervisors }\end{array}$ & & \\
\hline
\end{tabular}

Note:

Observer: 
Table 2. Academic supervision activities

\section{OBSERVATION FORM}

Object of observation : PWG activity

Meeting topic : Academic supervision

Place of observation:

Time of observation :

Type of observation : Descriptive

\begin{tabular}{|c|c|c|c|}
\hline No. & Aspect observation & Sub-aspects & Description of observation results \\
\hline \multirow[t]{2}{*}{1} & \multirow[t]{2}{*}{ Condition of activities } & $\begin{array}{l}\text { Presence of school } \\
\text { principals attendance } \\
\text { of school }\end{array}$ & \\
\hline & & Supervisors & \\
\hline \multirow[t]{2}{*}{2} & \multirow{2}{*}{$\begin{array}{l}\text { Delivery of material by } \\
\text { school supervisors }\end{array}$} & Material presented & \\
\hline & & $\begin{array}{l}\text { Situation when } \\
\text { delivering material }\end{array}$ & \\
\hline 3 & $\begin{array}{l}\text { Interactions between } \\
\text { school supervisors and } \\
\text { principals who are } \\
\text { present }\end{array}$ & & \\
\hline 4 & $\begin{array}{l}\text { Interactions between } \\
\text { school principals }\end{array}$ & & \\
\hline 5 & Discussion activities & Discussion situations & \\
\hline 6 & $\begin{array}{l}\text { Asking activities of } \\
\text { school principals to } \\
\text { school supervisors }\end{array}$ & & \\
\hline
\end{tabular}

Note:

Observer: 


\subsection{Data analysis}

Analysis in qualitative research is carried out when data collection occurs and after completing data collection within a certain period. After each interview, an analysis was carried out. According to Miles and Huberman, qualitative data analysis is carried out continuously and interactively to obtain saturated data. Data analysis activities are data reduction, data display and conclusion. Each of them is described as follows:

\subsubsection{Data reduction}

During interviews or observations, much data is recorded. Nevertheless, not all data are required. Unnecessary data is discarded, and then the necessary data is sorted according to the aspects studied and coded.

\subsubsection{Display data}

After the data is reduced, then it presents the data. Data presentation is a description of a structured collection of information that makes it possible to draw conclusions and take action. In this case, the data that has been reduced is presented in the form of narrative text, which is arranged systematically so that it is easy to understand and makes it easier to conclude.

\subsubsection{Conclusion}

From the beginning of data collection, conclusions have been drawn by looking for the meaning of each symptom obtained in the field, noting the regularity or pattern of explanations and configurations that may have a distinctive path. As long as the research is ongoing, any conclusions set will be continuously verified until they are valid.

\subsection{Data validity test}

The validity test was conducted through triangulation. Data triangulation is intended to ensure accurate data is obtained. For this reason, the method used is to check data through different sources or techniques.

\section{Results}

\subsection{Interviews}

The interviews were conducted on three informants, namely school supervisors, principals and teachers. The interviews focused on the principal's activities in PWG activities and academic supervision in schools. The PWG activity was attended by all elementary school principals with the school superintendent as an escort.

The purpose of the PWG activity is to improve teacher competence. In PWG activities, school supervisors provide material on the competence of school principals, especially the competence of academic supervision to increase the knowledge of principals. In this activity, the principal can discuss with other principals, and the school supervisor directs the discussion. In this activity, the principal conveys the problems and obstacles faced in their respective schools, while other principals and school supervisors provide opinions and solutions.

The results and benefits of mentoring school supervisors in PWG activities positively impact the competence of school supervision. In Table 3, the competencies of the principal before and after participating in PWG activities are described. The interview theme consisted of the principal's 
knowledge and a series of academic methods implemented. Academic supervision consists of three stages, namely planning, implementation and follow-up.

Table 3. Interview results

\begin{tabular}{ccc}
\hline No. & \multicolumn{1}{c}{ Before mentoring } & \multicolumn{1}{c}{ After mentoring } \\
\hline 1 & $\begin{array}{l}\text { The principal does not have sufficient } \\
\text { knowledge and competence to carry } \\
\text { out academic supervision. }\end{array}$ & $\begin{array}{l}\text { The principal has sufficient knowledge and } \\
\text { competence to carry out academic supervision. }\end{array}$
\end{tabular}

2 Supervision planning stage:

- Does not carry out planning meetings.

- No supervision schedule is made so that implementation is incidental.

- Does not socialise the supervision aspect in detail.

- Preparing the supervision instrument from the school.

Supervision implementation phase:

- The principal is only an auditor who checks administrative completeness without providing guidance and guidance to teachers.

- The principal has not mastered the methods and techniques of guidance in improving performance teachers in schools.

Follow-up supervision:

- No follow-up
Supervisor supervision planning stage:

- Planning for academic supervision, starting with a small meeting between the principal, vice-principal of the curriculum and senior teachers.

- Following the meeting with teachers, socialising the implementation of academic supervision to implement academic supervision is determined.

- Supervision socialisation is explained in detail so that teachers prepare learning tools.

- Make a supervision instrument that has been modified according to the needs and conditions of the school (realistic and easy to implement).

Supervision implementation phase:

- The principal examines administratively and examines content to find out where the teacher's competency deficiencies lie.

- The principal has carried out academic supervision with various techniques. Techniques used: individually, in groups, direct observation in class during the learning process or observed outside the classroom.

Follow-up supervision:

- The principal, vice-principal for curriculum and senior teachers who act as supervisors 


$\begin{array}{lll}\text { No. } & \text { Before mentoring } \quad \text { After mentoring }\end{array}$

evaluate the implementation of supervision. This stage is to determine follow-up actions to improve teacher work professionalism.

- Require teachers to attend teacher working groups organised by schools or school clusters to improve teacher professionalism.

- The results of supervision are reported to the school supervisor.

\subsection{Observation}

This study observation focused on 1) mentoring activities by school supervisors on PWG activities and 2) principal supervision activities. Table 4 describes the observation activities of school principals and school supervisors during PWG activities. In addition, the atmosphere of interaction between principals and school supervisors is described. The overall observation results are shown in Table 4.

Table 4. Observation results

\begin{tabular}{|c|c|c|}
\hline No & Activity & Observation data \\
\hline & PWG & $\begin{array}{l}\text { - Attended by the principal of public elementary } \\
\text { schools and school supervisors. } \\
\text { - Supervisors fill out material on the competence of } \\
\text { principal supervision. } \\
\text { - Each school principal conveys the problems that } \\
\text { occur in the school, respectively. Other principals } \\
\text { provide opinions, thoughts and solutions. School } \\
\text { supervisors also provide directions and solutions. } \\
\text { - The school principal prepares a supervision } \\
\text { programme plan under the supervision of the } \\
\text { school supervisor. } \\
\text { The principal seemed enthusiastic about } \\
\text { participating in the PWG activities. Relaxed and } \\
\text { friendly atmosphere. }\end{array}$ \\
\hline
\end{tabular}

2 Academic supervision activities by the principal
- The principal sits in the back seat, observing the teacher teaching.

- The supervisor assesses the teaching teacher based on the supervision instrument that has been made.

\subsection{Documentation}


A document is physical evidence that complements and strengthens data from interviews and observations. In Table 5, the documents obtained in the PWG activities and academic supervision by the school principal are described. Academic supervision activities are divided into three stages of activities, namely planning, implementation and follow-up.

\section{Table 5. Documentation}

\begin{tabular}{|c|c|c|}
\hline No. & Activity & Document \\
\hline 1 & PWG activities & $\begin{array}{ll} & \text { Attendance list } \\
\text { - } & \text { Photos of PWG activities }\end{array}$ \\
\hline 2 & Academic supervision planning & $\begin{array}{l}\text { - } \quad \text { Meeting attendance list } \\
\text { - } \quad \text { Minutes } \\
\text { - } \quad \text { Supervision schedule }\end{array}$ \\
\hline 3 & $\begin{array}{l}\text { Implementation of academic } \\
\text { supervision }\end{array}$ & $\begin{array}{l}\text { - Daily reports } \\
\text { - } \quad \text { Teacher assessment sheets }\end{array}$ \\
\hline 4 & Follow-up academic supervision & $\begin{array}{l}\text { - Photos of activities } \\
\text { - } \quad \text { Reports of academic supervision activities to } \\
\text { supervisors schools }\end{array}$ \\
\hline
\end{tabular}

\section{Discussion}

\subsection{PWG activities}

There are three parties that are considered to be very decisive in achieving educational goals, namely supervisors, school principals and teachers. Each party has a strategic role, which collaborates to achieve the expected educational goals. The task of the school supervisor is to provide guidance and coaching to school principals and teachers. The principal's task is to manage the school and carry out the teaching and learning process properly (Azainil et al., 2021; Maskur et al., 2018). Meanwhile, the teacher's task is to carry out the learning process (Alfian et al., 2019; Wiyono et al., 2020).

In order for the principal to work in a planned and directed manner, a school supervisor is needed who can foster and guide the implementation of his duties as a principal (Alfian et al., 2019; Arman et al., 2016). In addition, to become a professional principal, a forum is needed to develop his potential so that he can share his experiences with other school principals. The professional forum for empowering school principals is PWG (Vennebo \& Aas, 2020).

School supervisors accompany PWG activities that aim to improve the academic supervision competence of school principals. The competence of academic supervision is to foster teachers in improving the quality of the learning process. In this activity, school supervisors fill out material on the supervisory competence of principals, in theory and their application. The teaching applied by school supervisors is through lectures, discussions and the practice of planning academic supervision. The 
four principals who attended were enthusiastic in participating in this activity. They realised that knowledge of academic supervision is greatly needed in carrying out their duties and functions as school principals.

PWG activities have become a discussion forum and have found various solutions to problems faced by school principals. The implementation of PWG shows an atmosphere that supports work productivity. During the meeting, the principals were more open to asking questions that were not understood and were not apparent to the school supervisor. In addition, they conveyed the obstacles faced in carrying out supervision activities in schools. The principals seemed more motivated to improve their competencies; this can be seen from the questions submitted.

After getting the material from the school supervisor, the principals made an academic supervision plan for each school. Principals discussed and exchanged ideas about the problems faced at school. If the discussion does not find common ground, school supervisors provide suggestions and solutions. The principals felt comfortable discussing with colleagues under the direction of the school supervisor.

The principals said that implementing the PWG programme had provided inspiration and understanding in implementing the academic supervision programme. The series of academic supervision activities consist of 1) planning academic supervision programmes, 2) carrying out academic supervision of teachers using appropriate supervision approaches and techniques and 3 ) following-up on academic supervision activities in order to increase teacher professionalism (Honig \& Rainey, 2019; Noor et al., 2020). The principals also said that they increased their knowledge, insight and competence regarding academic supervision after participating in the PWG activity. The achievements of the principals through PWG activities following the PWG objectives are to improve their ability, knowledge and skills (Vennebo \& Aas, 2020).

\subsection{Planning, implementation and follow-up of academic supervision}

\subsubsection{Planning}

After participating in PWG activities, the competence that school principals can possess is to make plans for academic supervision. The principles that need to be considered in planning academic supervision are related to objectivity, responsibility and sustainability based on the needs and conditions of the school.

The principals carried out academic supervision planning through a meeting. First, the principal held a small meeting attended by the vice-principal for curriculum and senior teachers. At this meeting, they determined the goals, targets to be achieved and created a team of assistant principals to implement academic supervision. The implementation of supervision could be more directed and effective if it refers to the planning made professionally (Honig \& Rainey, 2019; Hvidston et al., 2018; Noor et al., 2020). Next, the principal held a meeting with the teachers to socialise the academic supervision programme. At the meeting, they determined the schedule for the implementation of academic supervision agreed upon by the teacher. The principal also conveyed the purpose of holding academic supervision, namely to improve the learning process. In detail, the principal explained the components being supervised, namely classroom administration, learning tools and implementation of the learning process. Learning tools include learning implementation plans, student worksheets, learning media and assessment instruments. The explanation given by the principal is clear, so the teacher understands what must be prepared during supervision. 
During the planning of academic supervision programmes, teachers are involved in being responsible for its implementation. In addition, they can find out the schedule for academic supervision that will be carried out to prepare themselves to complete class administration and learning tools. With the togetherness in preparing the programme, all parties will feel appreciated and will be able to eliminate misunderstandings between the principal and the teacher. Following the school's management, the principal involves the school community in the planning of the programme so that all are responsible for the implementation of the school programme (Mulawarman et al., 2021).

The arrangement of the academic supervision programme shows an increase in the knowledge and competence of school principals after participating in the PWG programme. Previously, school principals were not able to make supervision plans, so that the direction and purpose of supervision were not clear.

\subsubsection{Implementation}

Implementation of academic supervision by principals on teachers is essential to improve teacher performance abilities and learning quality through a good learning process (Maskur et al., 2018; Messi et al., 2018; Wiyono et al., 2020). In the implementation of supervision, the principal must treat teachers as people who have the potential to progress and develop better so that the emphasis on activities is more directed towards the process of improving (Alfian et al., 2019; Honig \& Rainey, 2020; Hoque et al., 2020). The principals in carrying out supervision with techniques, namely individually and in groups, are adjusted to the needs. Individual techniques in the form of supervision of class visits are carried out based on a predetermined schedule. Teacher performance appraisal by the supervisor is based on the assessment instrument that has been prepared. The supervisors are principals, vice-principals for curriculum or senior teachers. The group supervision technique is carried out by holding a meeting with the teacher to guide the general learning process.

Class administration assessments and learning tools have been checked directly by the supervisor before making class visits. This is carried out so that they focus more on observing the teacher in the learning process when supervising class visits. The class visit technique makes it easier for principals to get information about the strengths and weaknesses of teachers when teaching (Fahmi et al., 2019; Honig \& Rainey, 2019; Noor et al., 2020). The principals' direct observation of the learning process makes it easier for them to improve the learning process (Azainil et al., 2021; Hoque et al., 2020; Wiyono et al., 2020).

In general, the technical implementation of academic supervision takes place according to plan. Only because there were some obstacles, there was a delayed supervision schedule, but all schedules could be completed.

\subsubsection{Follow-up}

The principals, together with the supervisor team, provided feedback as a follow-up to academic supervision. Feedback given to teachers varied. There were improvements in learning tools. There were also about classroom management. Thus, the teachers understood their shortcomings and must make improvements in the following learning process. These improvements must always be controlled by the principal so that quality learning is achieved.

The results of the implementation of academic supervision are reported to the school supervisor. Based on the supervisory report, the principal and school supervisor discussed the next 
steps to improve teachers' performance and professionalism. Follow-up was carried out in the form of training or workshops on making learning tools, making media or classroom management skills.

As the purpose of the academic supervision programme is to improve the learning process. The academic supervision programme is not only used to assess teacher performance, but also the assessment, which is used to provide feedback and determine follow-up so that the following learning process is even better. So this academic supervision programme is sustainable and continuous (Agih, 2015; Alsaleh et al., 2017; Arman et al., 2016; Khun-Inkeeree et al., 2019).

The results showed that school principals had better academic supervision competencies than before receiving assistance from school supervisors in PWG activities (Table 3). The principals can carry out the planning, implementation and follow-up stages of academic supervision following the standards set by the government.

The success of increasing the supervisory competence of the principal cannot be separated from the activities of the principal in the PWG forum accompanied by the school supervisor. PWG is a forum or professional organisation for school principals. A forum that can provide opportunities for principals to develop their potential and share experiences with other principals. A school principal, in carrying out his duties and functions, sometimes experiences obstacles. In this form of PWG, the principal gets input from his fellow principals to discuss and find solutions. Thus, the forum PWG has been working correctly, namely 1) recognising the problems and difficulties of the school related to the design, implementation and evaluation; 2) overcoming difficulties by principals; and 3) developing the professional capabilities of principals (Fitra, 2013; Santosoagusyahoocoid \& Samarinda, 2019).

\subsubsection{School superintendent's role as the mentor in PWG activities.}

The school supervisor is the person in charge of fostering and guiding the principal in improving school performance (Aldaihani, 2017; Alfian et al., 2019). Therefore, the principal is very competent in assisting PWG activities. When the principal discusses solving the problems faced at school, the school supervisor provides suggestions and alternatives that can be a solution. Thus, it turns out that the empowerment of PWG accompanied by school supervisors is very effective in increasing the supervisory competence of school principals.

\section{Conclusion}

In PWG activities, the principals can exchange ideas to prepare surveillance programmes and find solutions to solve school problems. Discussions are more effective because the discussion members have the same problems and professions. Supervisors as assistant provide direction and solutions to solve school problems.

Based on the research data, the principal's supervisory competence increased after mentoring was carried out by the school supervisor through the activities of the PWG. At the planning stage, the principal prepares a supervision schedule, supervision instruments and socialisation for teachers. At the implementation stage, supervision is been carried out with various techniques as needed. Meanwhile, at the follow-up stage, the principal provides feedback to the teacher to improve the performance and quality of the teaching and learning process. In addition, the principal plans followup actions to improve teacher professionalism in the form of workshops on making learning tools, making media and training in classroom management skills. 
Nurlaili, N., Warman, W., \& Raolah, R., (2021). Improvement of principals' supervision competence through accompaniment in principal working groups. Cypriot Journal of Educational Science, 16(4), 1704-1720. https://doi.org/10.18844/cjes.v16i4.6033

\section{Recommendations}

Based on the findings, we suggest that principals utilise the PWG forum for discussion forums related to the principal's duties and programmes of academic supervision to improve teacher professionalism and the quality of the learning process.

\section{References}

Agih, A. (2015). Effective school management and supervision: Imperative for quality education service delivery. African Research Review, 9(3), 62. https://doi.org/10.4314/afrrev.v9i3.6

Aldaihani, S. G. (2017). Effect of prevalent supervisory styles on teaching performance in Kuwaiti high schools. Asian Social Science, 13(4), 25. https://doi.org/10.5539/ass.v13n4p25

Alfian, Wiyono, B. B., Imron, A., \& Humaisi, M. S. (2019). Development of the supervision model based on clinical approach to increase managerial competence of school principal. Universal Journal of Educational Research, 7(11), 2472-2481. https://doi.org/10.13189/ujer.2019.071126

Alsaleh, A., Alabdulhadi, M., \& Alrwaished, N. (2017). Impact of peer coaching strategy on pre-service teachers' professional development growth in Kuwait. International Journal of Educational Research, 86, 36-49. https://doi.org/10.1016/j.ijer.2017.07.011

Arman, Thalib, S. B., \& Manda, D. (2016). The effect of school supervisors competence and school principals competence on work motivation and performance of Junior High School teachers in Maros Regency, Indonesia. International Journal of Environmental and Science Education, 11(15), 7309-7317. http://www.ijese.net/makale_indir/IJESE_1000_article_57e3ccd4b7f9d.pdf

Astika, Y. W., Fitriyani, F., \& Burhanuddin, B. (2020). Implementasi peraturan menteri pendidikan nasional nomor 13 tahun 2007 tentang standar kompetensi kepala sekolah. CERMIN: Jurnal Penelitian, 4(2), 255-268. https://doi.org/10.36841/cermin_unars.v4i2.769

Astuti, S. (2017). Supervisi akademik untuk meningkatkan kompetensi guru di SD laboratorium UKSW. Scholaria: Jurnal Pendidikan Dan Kebudayaan, 7(1), 49-59. https://doi.org/10.24246/j.scholaria.2017.v7.i1.p49-59

Azainil, A., Komariyah, L., \& Yan, Y. (2021). The effect of principal's managerial competence and teacher discipline on teacher productivity. Cypriot Journal of Educational Sciences, 16(2), 563-579. https://doi.org/10.18844/cjes.v16i2.5634

Darishah, P., Daud, Y., \& Fauzee, M. S. O. (2017). Teaching and learning supervision by school management, attitude of teachers and competency of teaching. International Journal of Development and Sustainability, 6(10), 2186-8662. https://isdsnet.com/ijds-v6n10-13.pdf

Fahmi, C. N., Murniati, A. R., Nurliza, E., \& Usman, N. (2019). The implementation of academic supervision in improving teacher competency at primary school. Jurnal Ilmiah Peuradeun, 7(1), 181-194. https://doi.org/10.26811/peuradeun.v7i1.202

Fitra, R. A. (2013). Pelaksanaan fungsi kelompok kerja kepala sekolah dasar negeri kecamatan koto tangah kota padang. Bahana Manajemen Pendidikan, 1(1), 391-399. https://doi.org/10.24036/bmp.v1i1.2718

Hidayat, R., \& Ulya, H. (2019). Kompetensi kepala sekolah abad 21: Sebuah tinjauan teoretis. Jurnal Kepemimpinan Dan Pengurusan Sekolah, 4(1), 61-68. https://doi.org/10.34125/kp.v4i1.394

Honig, M. I., \& Rainey, L. R. (2019). Supporting principal supervisors: What really matters? Journal of Educational Administration, 57(5), 445-462. https://doi.org/10.1108/JEA-05-2019-0089 
Nurlaili, N., Warman, W., \& Raolah, R., (2021). Improvement of principals' supervision competence through accompaniment in principal working groups. Cypriot Journal of Educational Science, 16(4), 1704-1720. https://doi.org/10.18844/cjes.v16i4.6033

Honig, M. I., \& Rainey, L. R. (2020). A teaching-and-learning approach to principal supervision. Phi Delta Kappan, 102(2), 54-57. https://doi.org/10.1177/0031721720963234

Hoque, K. E., Bt Kenayathulla, H. B., D/O Subramaniam, M. V., \& Islam, R. (2020). Relationships between supervision and teachers' performance and attitude in secondary schools in Malaysia. SAGE Open, 10(2). https://doi.org/10.1177/2158244020925501

Hudiyono, Y., Rokhmansyah, A., \& Elyana, K. (2021). Class conversation strategies in junior high schools: Study of conversation analysis. Cypriot Journal of Educational Sciences, 16(2), 725-738. https://doi.org/10.18844/cjes.v16i2.5649

Hvidston, D. J., McKim, C. A., \& Holmes, W. T. (2018). What are principals' perceptions? Recommendations for improving the supervision and evaluation of principals. NASSP Bulletin, 102(3), 214-227. https://doi.org/10.1177/0192636518802033

Khun-Inkeeree, H., Dali, P. D., Daud, Y., Fauzee, M. S. O., \& Khalid, R. (2019). Effects of teaching and learning supervision on teachers attitudes to supervision at secondary school in Kubang Pasu District, Kedah. International Journal of Instruction, 12(1), 1335-1350. https://doi.org/10.29333/iji.2019.12185a

Kotirde, I. Y., \& Yunos, J. B. M. (2015). The processes of supervisions in secondary schools educational system in Nigeria. Procedia - Social and Behavioral Sciences, 204, 259-264. https://doi.org/10.1016/j.sbspro.2015.08.149

Maskur, M., Haryono, H., \& Hidayah, I. (2018). Contribution of supervision of school supervisor and school quality culture on primary school's managerial competence. Educational Management, 7(1), 25-32. https://journal.unnes.ac.id/sju/index.php/eduman/article/view/22935

Messi, M., Sari, W. A., \& Murniyati, M. (2018). Pelaksanaan supervisi akademik pengawas sekolah sebagai upaya peningkatan profesionalisme guru. JMKSP (Jurnal Manajemen, Kepemimpinan, Dan Supervisi Pendidikan), 3(1), 114-125. https://doi.org/10.31851/jmksp.v3i1.1583

Moleong, L. J. (2017). Metodologi penelitian kualitatif (Revisi). PT Remaja Rosdakarya.

Mulawarman, W. G., Komariyah, L., \& Suryaningsi, S. (2021). Women and leadership style in school management: Study of gender perspective. Cypriot Journal of Educational Sciences, 16(2), 594-611. https://doi.org/10.18844/cjes.v16i2.5638

Murtiningsih, M., Kristiawan, M., \& Lian, B. (2019). The correlation between supervision of headmaster and interpersonal communication with work ethos of the teacher. European Journal of Education Studies, 6(1), 246-256. https://doi.org/10.5281/zenodo.2649535

Noor, I. H. M., Herlinawati, \& Sofyaningrum, E. (2020). The academic supervision of the school principal: A case in Indonesia. Journal of Educational and Social Research, 10(4), 81-93. https://doi.org/10.36941/JESR2020-0067

Ramadhan, A. (2017). Pengaruh pelaksanaan supervisi akademik pengawas sekolah dan supervisi kepala sekolah terhadap kinerja guru SMK Negeri di Kabupaten Majene. Journal of Educational Science and Technology (EST), 3(2), 136-144. https://doi.org/10.26858/est.v3i2.3579

Rokhmansyah, A., Nuryatin, A., Supriyanto, T, \& Setyaningsih, N. H. (2021). Evaluation of Reading materials for students in schools. Cypriot Journal of Educational Sciences, 16(3), 1097-1105. https://doi.org/10.18844/cjes.v16i3.5828

Santoso, A., Achmad, A., \& Wardana, M. I. (2019). Pengaruh Program Musyawarah Guru Mata Pelajaran (MGMP) dan Musyawarah Kelompok Kerja Kepala Sekolah (MKKKS) terhadap Peningkatan Kinerja Guru di Kabupaten Kutai Kartanegara. Syamil, 7(1), 71-85. https://doi.org/10.21093/sy.v7i1.1655

Syafmawati, I. (2020). Persepsi guru tentang kompetensi supervisi kepala sekolah SD Negeri Kecamatan Padang 
Nurlaili, N., Warman, W., \& Raolah, R., (2021). Improvement of principals' supervision competence through accompaniment in principal working groups. Cypriot Journal of Educational Science, 16(4), 1704-1720. https://doi.org/10.18844/cjes.v16i4.6033

Timur Kota Padang. Jurnal Bahana Manajemen Pendidikan, 1(1). https://doi.org/10.24036/bmp.v1i1.2685

Trinh, T. P. T., Pham, T. Van, Cao, H. T., Nguyen, T.-T., Nghiem, T. T., \& Tran, T. (2019). The profile of professional standards for secondary school principals in Vietnam. International Journal of Education and Practice, 7(4), 310-323. https://eric.ed.gov/?id=EJ1239169

Vennebo, K. F., \& Aas, M. (2020). A supportive tool for principals in guiding professional group discussions. Educational Research, 62(3), 266-283. https://doi.org/10.1080/00131881.2020.1796518

Wiyono, B. B., Burhanuddin, \& Maisyaroh. (2020). Comparative effect of the supervision of the principal and quality of organizational management in school education. Utopia y Praxis Latinoamericana, 25(Extra10), 1-13. https://doi.org/10.5281/zenodo.4155681

Yasin, U., \& Mustafa, F. (2020). The correlation between school principal leadership competence and teachers' social behaviours. IRJE: Indonesian Research Journal in Education, 151-170. https://onlinejournal.unja.ac.id/irje/article/download/9093/6501/28427 